\title{
Comparison of The Two Lipoprotein Apheresis Methods in The Treatment of Familial Hypercholesterolemia
}

\section{Familial Hiperkolesterolemi Tedavisinde Iki Lipoprotein Aferezi Yönteminin Karşılaştırılması}

\author{
Ozcan Ceneli ${ }^{1}$, Mehmet Ali Karaselek ${ }^{1}$, Atakan Tekinalp ${ }^{1}$, Sinan Demircioglu ${ }^{1}$, Mustafa Kulaksizoglu ${ }^{2}$
}

${ }^{1}$ Necmettin Erbakan University, Meram Faculty of Medicine, Division of Hematology Konya, Turkey

${ }^{2}$ Necmettin Erbakan University, Meram Faculty of Medicine, Division of Endocrinology and Metabolism, Konya, Turkey

Address correspondence to: Ozcan Ceneli, Necmettin Erbakan University, Meram Faculty of Medicine, Division of Hematology, Konya, Turkey

e-mail: cenelio@yahoo.com

Geliş Tarihi/Received: 26 October 2020 Kabul Tarihi/Accepted: 17 April 2021

\begin{abstract}
Öz
Amaç: Ailesel hiperkolesterolemi düşük dansiteli lipoprotein kolesterol düzeyinin önemli derecede yükselmesine ve erken yaşta koroner arter hastalığı ile kalp nedenli ölüme yol açan otozomal dominant kalıtımlı bir genetik hastalıktır. Bu hastalığın heterozigot ve homozigot formları vardır ve insidansları sırasıyla 1:500 ve 1:1 000000 olarak rapor edilmiştir. Bu hastalık sıklıkla LDL reseptörü (en sık), apolipoprotein B (Apo B), proprotein konvertaz subtilisin/cexin 9 (PCSK9) ve LDL reseptör adaptör proteini (LDLRAP) gen mutasyonları nedeniyle ortaya çıkmaktadır. Ailesel hiperkolesterolemili hastalar statin gibi lipid-düşürücü tedavilere iyi yanıt vermez ve bu nedenle lipoprotein aferezi seçkin tedavi yöntemidir. Hastalar ve Yöntem: Homozigot ailesel hiperkolesterolemi tanısı alan 20 yaşında kadın hastada, çift filtrasyon plazmaferez (DFPP) ve dekstran sülfat kolonu (DSC) olmak üzere farklı iki lipoprotein aferez yönteminin sonuçlarını karşılaştırdık. 20 seans çift filtrasyon plazmaferez (DFPP) ve 20 seans dekstran sülfat kolonu (DSC), toplam 40 aferez seansı değerlendirildi.

Bulgular: Íki yöntemin karşılaştırılmasında, yüksek dansiteli lipoprotein (YDL), lökosit, platelet, potasyum, kalsiyum, protrombin zamanı ve aktive parsiyel tromboplastin zamanı değerleri değişiklikleri istatistiksel olarak anlamlı bulundu.

Sonuç: Sonuç olarak, çalışmamız iki farklı yöntemin serum elektrolit değerleri, hemostaz ölçütleri ve lökosit, trombosit sayılarına farklı etkileri olduğunu gösterdiği için, aferez yöntemi seçiminin hastanın klinik ve laboratuvar bulgularına göre yapılmasının daha uygun olacağını düşündürmektedir.
\end{abstract}

Anahtar Kelimeler: Aferez, ailesel hiperkolesterolemi, düşük-dansiteli lipoprotein kolesterol

\section{Abstract}

Aim: Familial hypercholesterolemia $(\mathrm{FH})$ is an autosomal dominant inherited genetic disorder that causes a significant increase in low-density lipoprotein (LDL) cholesterol levels and leads to early coronary heart disease and cardiac mortality. Although this disease has a heterozygous (HeFH) and homozygous (HoFH) form, the incidence of HeFH is reported to be 1: 500, while HoFH is reported to be 1: 1000000 . This disease is often caused by LDL receptor (most common), apolipoprotein B (Apo B), Proprotein Convertase Subtilisin/Kexin 9 (PCSK9), and LDL receptor adaptor protein (LDLRAP) gene mutations. Patients with $\mathrm{FH}$ do not respond well to lipid-lowering therapies such as a statin, and so lipoprotein apheresis is the treatment of choice.

Patients and Methods: We compared the results of lipoprotein apheresis in a 20-year-old female patient diagnosed with HoFH with two different methods [double-filtration plasmapheresis (DFPP) and dextran sulfate column (DSC) methods]. 40 lipoprotein apheresis procedures including 20 sessions of DFPP and 20 sessions of DSC were evaluated.

Results: When the two methods were compared the changes in high-density lipoprotein, white blood cells, platelets, potassium, calcium, prothrombin time (INR) and activated partial thromboplastin time values were statistically significant.

Conclusions: In conclusion, our study suggests that it would be more appropriate to choose the apheresis method according to the clinical and laboratory findings of the patient since it shows that two different methods have different effects on serum electrolyte values, hemostasis criteria and leukocyte and platelet counts.

Key words: Apheresis, familial hypercholesterolemia, low-density lipoprotein cholesterol
Cite this article as: Ceneli $O$, Karaselek MA, Tekinalp A, Demircioglu $S$, Kulaksizoglu M. Comparison of The Two Lipoprotein Apheresis Methods in The Treatment of Familial Hypercholesterolemia. Selcuk Med J 2021;37(2): 118-123
Disclosure: None of the authors has a financial interest in any of the products, devices, or drugs mentioned in this article. The research was not sponsored by an outside organization. All authors have agreed to allow full access to the primary data and to allow the journal to review the data if requested. 


\section{INTRODUCTION}

Familial hypercholesterolemia $(\mathrm{FH})$ is an autosomal dominant inherited disease that causes atherosclerosis and premature death from coronary heart disease $(1,2)$. Mutations in the apolipoprotein $B$ and generally LDL (low-density lipoprotein) receptor gene cause $\mathrm{FH}$. These mutations lead to the formation of non-functional LDL receptors or to decrease the number of LDL receptors (3-6). Although there are homozygous and heterozygous forms $(\mathrm{HeFH})$ of this disease, homozygous $(\mathrm{HoFH})$ individuals are more affected by the disease, and severe hypercholesterolemia is seen (LDL level is $600-1000 \mathrm{mg} / \mathrm{dL}$ ). Although LDL levels of individuals with $\mathrm{HeFH}$ can generally be controlled by statinderived drugs, LDL levels of HoFH patients cannot be adequately controlled by statins and other lipidlowering drugs. In recent years, new lipid-lowering drugs such as PCSK9i (Proprotein Convertase Subtilisin/Kexin type 9 inhibitors) and lomitapide have been developed. The PCSK9 monoclonal antibody evolocumab can be used in $\mathrm{HoFH}$ and $\mathrm{HeFH}$ patients with high cardiovascular risk. Alirocumab is used in $\mathrm{HeFH}$ patients. The addition of lomitapide to standard lipid-lowering therapy also reduces plasma LDL cholesterol levels. However, lipoprotein apheresis remains among the treatment options in patients with familial hypercholesterolemia (7).

Lipoprotein apheresis is an apheresis method developed for patients with $\mathrm{FH}$ and is used to reduce LDL cholesterol (8). Lipoprotein apheresis methods include double filtration plasmapheresis (DFPP), dextran sulfate column (DSC), heparininduced extracorporeal LDL precipitation (HELP), immunoadsorption, polyacrylate-coated polyacrylamide direct perfusion. In these methods, LDL cholesterol reduction is based on charge (dextran sulfate and polyacrylate), size (double filtration), precipitation at low $\mathrm{pH}$ (HELP), or immuno-absorption with anti-Apo B-100 antibodies (9). Although these methods have advantages and disadvantages compared to each other, the most preferred methods in terms of cost, usage, and accessibility in lipoprotein apheresis are DFPP, DSC, and HELP. Therefore, in this retrospective study, we aimed to compare the double filtration (DFPP, based on size) and dextran sulfate column (DSC, based on charge) methods of lipoprotein apheresis in terms of lipid parameters, other biochemical parameters, hematological and coagulation values in a patient with $\mathrm{HoFH}$.

\section{PATIENTS AND METHODS \\ Patient and Apheresis Procedures and Devices}

In this retrospective study, the results of two different lipoprotein apheresis methods that were performed between 2015 and 2017 of the 20-year-old female patient diagnosed with $\mathrm{HoFH}$, were analyzed. The study protocol was approved by the Ethics Committee (Necmettin Erbakan University, Faculty of Meram Medicine) with the 2019/2078 consent number. The study was performed according to the "Principles of the Helsinki Declaration". The diagnosis of the patient was "Definite Familial Hypercholesterolemia" according to Simon Broome's diagnostic criteria. The patient's lipid profile at admission was as follows; lipoprotein a level $68.5 \mathrm{mg} / \mathrm{dL}$ (Reference range 0-30 $\mathrm{mg} / \mathrm{dL}$ ), total cholesterol $705 \mathrm{mg} / \mathrm{dL}$ (Reference range $0-200 \mathrm{mg} / \mathrm{dL}$ ), LDL-cholesterol $647 \mathrm{mg} / \mathrm{dL}$ (Reference range $<100 \mathrm{mg} / \mathrm{dL}$ ), HDL-cholesterol $36.4 \mathrm{mg} / \mathrm{dL}$ (Reference range 40-60mg/dL). Physical examination revealed tendon xanthomas. There was no history of cardiovascular events. Since the diagnosis, the patient had been using acetylsalicylic acid as antiaggregation therapy, and ezetimibe 10 $\mathrm{mg} /$ day, rosuvastatin $40 \mathrm{mg} /$ day, cholestyramine 12 $\mathrm{g} /$ day divided in 3 doses as lipid-lowering drugs, but adequate control of the lipids could not be achieved. New cholesterol-lowering drugs such as evolocumab and lomitapide could not be used because they were not available. Totally 40 Lipoprotein apheresis procedures including 20 sessions of DSC and 20 sessions of DFPP were evaluated. Therapeutic apheresis modality was changed in this patient because of institutional apheresis sets supply.

Apheresis sessions were performed regularly with an interval of 15 days. The first 20 apheresis sessions of the patient were done with the DSC method and the next 20 sessions with the DFPP method. Two blood volumes were processed in the DSC method and one plasma volume was processed in the DFPP method. In the DSC method, acid citrate dextrose at a ratio of 1:12 was used according to the blood pump speed ratio. In the DFPP method, $30 \mathrm{U} / \mathrm{kg}$ iv bolus heparin loading dose and $10 \mathrm{U} / \mathrm{kg}$ maintenance dose were used. Apheresis sessions with DSC and DFPP methods were performed with the Kaneka DX21 device and the Asahi KASEI plasauto $\Sigma$ device, respectively. The column containing dextran sulfate bonded cellulose (Liposorber® DL-75) in the DSC method and a filter with polycarbonate (Cascadeflo EC-50W) in the DFPP method were used. During the procedure, the patient was monitored for possible 
complications.

Pre- and post-procedural venous blood samples were obtained from the patient. Post-procedural blood samples were drawn at least 2 hours after apheresis ended. After the procedure, total blood volume processed, total plasma volume processed, procedure duration, and complications were noted on the procedure form. LDL, high-density lipoprotein (HDL), total cholesterol, blood urea nitrogen (BUN), urea, creatinine $(\mathrm{Cr})$, sodium $(\mathrm{Na})$, potassium $(\mathrm{K})$, calcium (Ca), Albumin (Alb), white blood cell (WBC), hemoglobin ( $\mathrm{Hgb})$, platelets (PIt), INR and aPTT were analyzed. Also, procedures were evaluated in terms of procedure duration and complications. All patients and/or first-degree relatives were given information about the process and Lipoprotein apheresis information/consent forms were filled out by patients or first-degree relatives before the process.

\section{Statistical Analysis}

Study data were tested with the normality test Shapiro-Wilk for each group. Parameter comparison of the two devices before and after the procedure was tested with Repeated measure variance analysis. This test was used to evaluate both the change in parameters before and after the procedure and the difference between the groups. Sphericity assumption was again made with this test to evaluate normality. $F$ and probability $(p)$ values obtained from Huynh-Feldt corrections were used if GreenhouseGeisser $>0.75$ if epsilon value $<0.75$ did not meet Sphericity assumption. Pre- and post-procedure changes and interaction effects of the groups were evaluated from the "within-subject effects" table. The "Between subject effects" table was used to see the difference between groups regardless of change. Tables are given as mean and standard deviation. Statistical analysis was performed with open source JASP (vers.0.9.0.1. University of Amsterdam. https:// jasp-stats.org/) statistical software. $p<0.05$ was considered statistically significant.

\section{RESULTS}

The lipoprotein apheresis treatment performed by DSC and DFPP method is shown in Table 1 before and after treatment. Lipoprotein apheresis was performed by processing an average of 7000 (9000-7000 \pm

Table 1. Values of before and after lipoprotein apheresis procedures performed by DFPP and DSC method

\begin{tabular}{|c|c|c|c|c|c|c|c|}
\hline Parameters & $\begin{array}{l}\text { Before } \\
\text { (Mean } \pm S D)\end{array}$ & $\begin{array}{l}\text { DFPP method } \\
\text { After } \\
\text { (Mean } \pm S D)\end{array}$ & $\begin{array}{l}\text { Change } \\
(\%)\end{array}$ & $\begin{array}{l}\text { Before } \\
\text { (Mean } \pm S D)\end{array}$ & $\begin{array}{l}\text { DSC method } \\
\text { After } \\
\text { (Mean } \pm S D)\end{array}$ & $\begin{array}{l}\text { Change } \\
(\%)\end{array}$ & $\overline{p-v a l u e}$ \\
\hline $\begin{array}{l}\text { Total cholesterol } \\
(\mathrm{mg} / \mathrm{dL})\end{array}$ & $583.8 \pm 79.8$ & $192.7 \pm 52.3$ & $\begin{array}{l}\text { Decrease } \\
66.9\end{array}$ & $572.2 \pm 50.7$ & $238.6 \pm 34.8$ & $\begin{array}{l}\text { Decrease } \\
58.29\end{array}$ & 0.327 \\
\hline $\begin{array}{l}\text { Triglycerides } \\
(\mathrm{mg} / \mathrm{dL})\end{array}$ & $90.8 \pm 13.8$ & $66.2 \pm 14.1$ & $\begin{array}{l}\text { Decrease } \\
27\end{array}$ & $79.5 \pm 18.4$ & $71.4 \pm 18.6$ & $\begin{array}{l}\text { Decrease } \\
10.25\end{array}$ & 0.486 \\
\hline $\begin{array}{l}\text { LDL cholesterol } \\
(\mathrm{mg} / \mathrm{dL})\end{array}$ & $518.4 \pm 80.8$ & $151.5 \pm 50.2$ & $\begin{array}{l}\text { Decrease } \\
71.2\end{array}$ & $519.1 \pm 49.2$ & $193.9 \pm 34.8$ & $\begin{array}{l}\text { Decrease } \\
62.83\end{array}$ & 0.215 \\
\hline $\begin{array}{l}\text { HDL cholesterol } \\
(\mathrm{mg} / \mathrm{dL})\end{array}$ & $46.7 \pm 6.6$ & $27.8 \pm 5.6$ & $\begin{array}{l}\text { Decrease } \\
40.7\end{array}$ & $37.1 \pm 4.9$ & $29.1 \pm 3.6$ & $\begin{array}{l}\text { Decrease } \\
21.53\end{array}$ & 0.016 \\
\hline $\mathrm{K}(\mathrm{mmol} / \mathrm{dL})$ & $4.1 \pm 0.1$ & $4.02 \pm 0.2$ & $\begin{array}{l}\text { Decrease } \\
2.05\end{array}$ & $4 \pm 0.1$ & $3.6 \pm 0.2$ & $\begin{array}{l}\text { Decrease } \\
8.17\end{array}$ & $<0.001$ \\
\hline $\mathrm{Ca}(\mathrm{mg} / \mathrm{dL})$ & $9.3 \pm 0.3$ & $8.22 \pm 0.3$ & $\begin{array}{l}\text { Decrease } \\
11.67\end{array}$ & $9.3 \pm 0.1$ & $8.9 \pm 0.3$ & $\begin{array}{l}\text { Decrease } \\
4.54\end{array}$ & $<0.001$ \\
\hline $\mathrm{Na}(\mathrm{mmol} / \mathrm{dL})$ & $137.9 \pm 1.5$ & $140.1 \pm 2.2$ & $\begin{array}{l}\text { Increase } \\
2.23\end{array}$ & $136.2 \pm 2$ & $141.2 \pm 2.7$ & $\begin{array}{l}\text { Increase } \\
3.65\end{array}$ & 0.656 \\
\hline Albumin $(\mathrm{g} / \mathrm{dL})$ & $4.3 \pm 0.2$ & $3.71 \pm 0.3$ & $\begin{array}{l}\text { Decrease } \\
11.8\end{array}$ & $4.2 \pm 0.1$ & $3.6 \pm 0.3$ & $\begin{array}{l}\text { Decrease } \\
13.76\end{array}$ & 0.197 \\
\hline Urea $(\mathrm{mg} / \mathrm{dL})$ & $23.7 \pm 5.7$ & $26.5 \pm 5.2$ & $\begin{array}{l}\text { Increase } \\
10.2\end{array}$ & $22.2 \pm 4.6$ & $28.7 \pm 3.6$ & $\begin{array}{l}\text { Increase } \\
29.88\end{array}$ & 0.793 \\
\hline Creatinine $(\mathrm{mg} / \mathrm{dL})$ & $0.7 \pm 0.02$ & $0.6 \pm 0.06$ & $\begin{array}{l}\text { Decrease } \\
3.6\end{array}$ & $0.67 \pm 0.05$ & $0.68 \pm 0.04$ & $\begin{array}{l}\text { Increase } \\
2.17\end{array}$ & 0.536 \\
\hline WBC (103/uL) & $7.68 \pm 0.95$ & $10.26 \pm 2.92$ & $\begin{array}{l}\text { Increase } \\
33.53\end{array}$ & $6.84 \pm 0.96$ & $5.63 \pm 0.86$ & $\begin{array}{l}\text { Decrease } \\
17.69\end{array}$ & $<0.001$ \\
\hline $\mathrm{Hgb}(\mathrm{g} / \mathrm{dL})$ & $12.35 \pm 0.39$ & $12.53 \pm 0.78$ & $\begin{array}{l}\text { Decrease } \\
1.49\end{array}$ & $12.92 \pm 0.43$ & $11.79 \pm 0.53$ & $\begin{array}{l}\text { Decrease } \\
8.71\end{array}$ & 0.570 \\
\hline PLT $(x 103 / \mu L)$ & $231 \pm 14$ & $208 \pm 19$ & $\begin{array}{l}\text { Decrease } \\
9.73\end{array}$ & $214 \pm 22$ & $171 \pm 17$ & $\begin{array}{l}\text { Decrease } \\
19.92\end{array}$ & $<0.001$ \\
\hline INR & $1.07 \pm 0.5$ & $1.48 \pm 0.01$ & $\begin{array}{l}\text { Increase } \\
33.05\end{array}$ & $1.05 \pm 0.5$ & $1.28 \pm 0.06$ & $\begin{array}{l}\text { Increase } \\
22.49\end{array}$ & $<0.001$ \\
\hline aPTT (sec) & $33.88 \pm 1.35$ & $73.7 \pm 38.88$ & $\begin{array}{l}\text { Increase } \\
117\end{array}$ & $33 \pm 2.56$ & $107.49 \pm 31.63$ & $\begin{array}{l}\text { Increase } \\
233\end{array}$ & 0.007 \\
\hline
\end{tabular}


577.35) $\mathrm{mL}$ of whole blood in the DSC method and $2239(2700-1500 \pm 317.04) \mathrm{mL}$ of plasma in the DFPP method. Eventually, triglyceride, LDL, HDL, and total cholesterol levels were decreased in both methods. Triglyceride, LDL, and total cholesterol level drop were not statistically between the devices. In contrast, the decrease in HDL level between the two devices was found to be statistically significant $(p<0.05)$. The effect of two methods on other biochemical parameters was examined and it was found that $\mathrm{K}$ level decreased $2.05 \%$ by DFPP and $8.17 \%$ by the DSC method. Conversely, the decrease in Ca level was $11.7 \%$ in DFPP and $4.54 \%$ in DSC. These changes were statistically significant $(p<0.001)$.

The effect of the procedures on hematological parameters was determined in WBC, PIt, and coagulation tests. While Plt decreased in both methods, it decreased more in the DSC method and this decrease was statistically significant $(p<0.001)$. Also, an increase in coagulation test values was detected in both devices and this increase was found to be significant (INR $p<0.001$; aPTT $p=0.007$ ) (Table 1 and Figure 1). While WBC increased in the DFFP system, DSC also decreased. This change is statistically significant $(p<0.001)$.

\section{DISCUSSION}

$\mathrm{FH}$ is a rare inherited disease with a high LDL level and increases the risk of early cardiovascular disease. As with many other diseases, early diagnosis and

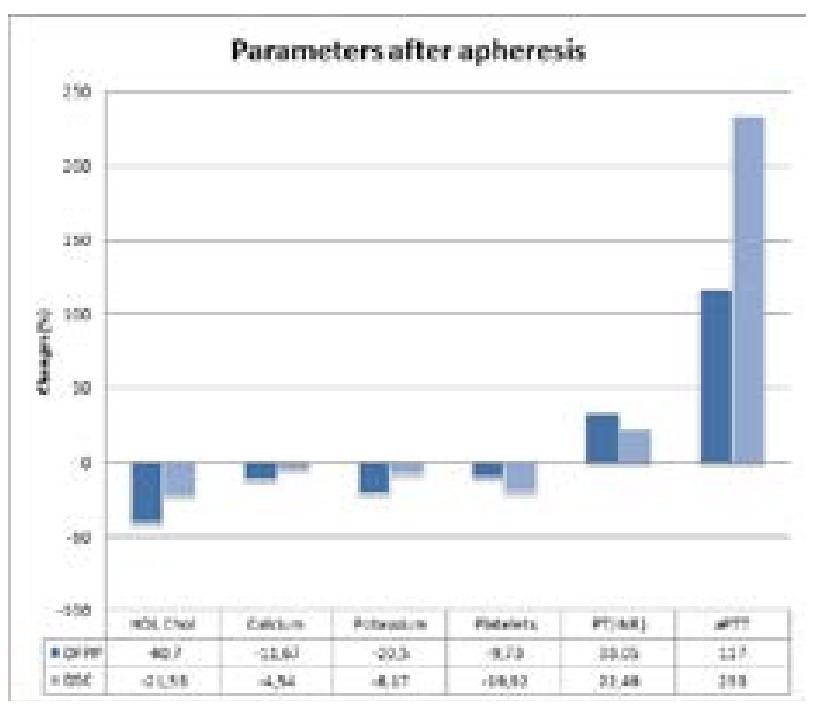

Figure 1. Changing parameters after two apheresis methods treatment of these patients reduce the risk of early atherosclerotic cardiovascular disease. In particular, patients with $\mathrm{HoFH}$ have been reported to initiate appropriate treatment as soon as possible, delaying major cardiovascular events and early death $(2,10)$. There are several treatment options for lowering LDL levels for $\mathrm{FH}$ patients. However, these patients do not respond adequately to conventional treatments $(11,12)$. In this case, Lipoprotein apheresis appears to be an alternative treatment option for these patients. Although our study was performed on one patient, this provided homogeneous data for the evaluation of two different apheresis methods.

There are many apheresis systems used in Lipoprotein apheresis. Some systems perform LDL absorption from plasma (DFPP, HELP, immunoadsorption), while some systems perform LDL absorption directly from whole blood (DSC, polyacrylate-coated polyacrylamide direct perfusion). Although these systems have advantages and disadvantages in terms of specificity, difficulty, safety, and cost, they are widely used in Lipoprotein apheresis (13). In the literature, LDL reduction rates were reported as $56 \%$ with the DFPP method and $62 \%$ with the DSC method (14-16). In our study, we achieved a $71 \%$ LDL reduction with the DFPP method and $62 \%$ with the DSC. LDL decline with DFPP was slightly higher than reported in the literature. The decrease with the DSC method was consistent with the literature. Also, HDL reduction rates were reported as $25 \%$ with DFPP and as $2.5-13 \%$ with DSC in the literature (16-18). In our study, these rates have emerged as $40 \%$ with DFPP and $21 \%$ with DSC. In the literature, HDL reduction has been reported due to the DFPP method rather than DSC. In their study, Adorni MP et al showed that LDL apheresis can alter HDL-cholesterol level, composition, and functionality (19). They concluded that lipid apheresis affecting serum cholesterol efflux capacity and therewithal reduces serum capacity to deliver cholesterol to macrophages, thus counteracting foam-cell formation. Our study also shows that the DSC method can also cause significant HDL reduction.

Although a decrease of $\mathrm{K}$ and $\mathrm{Ca}$ levels was not reported for both systems in the literature, a decrease was detected in our patient and it was found to be statistically significant. However, we think that it is not important for the patient with normal $\mathrm{Ca}$ and $\mathrm{K}$ levels because levels of $\mathrm{K}$ and $\mathrm{Ca}$ stayed within normal ranges after the procedure. Besides, these changed levels returned to normal after 12 hours. We 
believe that $\mathrm{K}$ and $\mathrm{Ca}$ values should be taken into consideration for the patients who have borderline $\mathrm{K}$ and $\mathrm{Ca}$ levels and method selection should be made. We observed WBC increase by the DFPP method and WBC decrease by DCS method and these changes were statistically significant. Although reductions were observed by DSC, the reason for the increment by DFPP was not fully understood.

Both methods reduced platelet count. However, the reduction was higher with the DSC method. In the follow-up of the patients, platelets count improved within 24 hours. Although platelet count is improved, it is thought that patients who have thrombocytopenia may be in the risk group for the DSC method. As previously reported in the literature, PT (INR) and aPTT prolongation were observed with both methods (20). APTT prolongation is thought to be secondary to the anticoagulant system used in the two apheresis techniques. However, despite the use of ACD in the DSC method, it was not understood why there was more APTT prolongation. When side effects related to coagulation are seen, when LDL and lipoprotein-a levels are not sufficiently reduced in the previous lipid apheresis method, when less saline infusion is required, when apheresis time is important for the patient, the apheresis center should be able to offer patients different methods of lipid apheresis (21). In conclusion, when the lipoprotein apheresis results of two different methods are evaluated in our study, it is clearly seen that both methods are safe and applicable for LDL removal. However, in our study, Ca, K, HDL-cholesterol, WBC, PIt, and PT, APTT changes difference was found between the two methods. Besides, $\mathrm{K}$ and $\mathrm{Ca}$ values should be taken into consideration for the patients who have borderline $\mathrm{K}$ and $\mathrm{Ca}$ levels. Therefore, considering the clinical and laboratory findings of the patient, we believe that the safest method should be chosen for the patient.

Conflict of interest: Authors declare that there is no conflict of interest between the authors of the article.

Financial conflict of interest: Authors declare that they did not receive any financial support in this study.

Address correspondence to: Ozcan Ceneli, Necmettin Erbakan University, Meram Faculty of Medicine, Division of Hematology, Konya, Turkey

e-mail: cenelio@yahoo.com

\section{REFERENCES}

1. Schuff-Werner P, Gohlke H, Bartmann U, et al. The HELPLDL-apheresis multicentre study, an angiographically assessed trial on the role of LDL-apheresis in the secondary prevention of coronary heart disease. II. Final evaluation of the effect of regular treatment on LDL-cholesterol plasma concentrations and the course of coronary heart disease. Eur J Clin Invest 1994;24(11):724-32.

2. Bouhairie VE, Goldberg AC. Familial hypercholesterolemia. Cardiol Clin 2015;33(2):169-79.

3. Whitfield AJ, Barrett PHR, van Bockxmeer FM, et al. Lipid disorders and mutations in the APOB gene. Clin Chem 2004; 50(10):1725-32.

4. Horton JD, Cohen JC, Hobbs HH. PCSK9: A convertase that coordinates LDL catabolism. The Journal of Lipid Research 2009;50:172-7.

5. Brown MS, Goldstein JL. A receptor-mediated pathway for cholesterol homeostasis. Science 1986;232 (4746):34-47.

6. Goldstein JL, Hobbs HH, Brown MS. The metabolic and molecular basis of inherited disease. New York: McGraw Hill, 2001.

7. Schöb $M$, Müller $P$, Gerth $Y Y$, et al. Diagnosis and treatment of familial hypercholesterolemia. Praxis 2018;107(24):134553.

8. Makino $\mathrm{H}$, Tamanaha T, Harad a-Shiba M. LDL apheresis in Japan. Transfus Apher Sci 2017; 56(5):677-81.

9. Schwartz J, Padmanabhan A, Aqui N, et al. Guidelines on the use of therapeutic apheresis in clinical practice-evidencebased approach from the writing committee of the american society for apheresis: The Seventh Special Issue. J Clin Apher 2016;31(3):149-62.

10. Raal FJ, Pilcher GJ, Panz VR, et al. Reduction in mortality in subjects with homozygous familial hypercholesterolemia associated with advances in lipid-lowering therapy. Circulation 2011;124:2202-07.

11. Nordestgaard B, Chapman M, Humphries S. Familial hypercholesterolaemia is underdiagnosed and undertreated in the general population: Guidance for clinician stop revent coronary heart disease. Consensus Statement of the European Atherosclerosis Society. Eur Heart $\mathrm{J}$ 2013;34(45):3478-90a.

12. Cuchel M, Bruckert E, Ginsberg H. Homozygous familial hypercholesterolaemia: New insights and guidance for clinicians to improve detection and clinical management. Eur Heart J 2014;35(32):2146-57.

13. Wang A, Richhariya A, Gandra SR, et al. Systematic review of low density lipoprotein cholesterol apheresis for the treatment of familial hypercholesterolemia. J Am Heart Assoc 2016;5(7):e003294.

14. Otto $C$, Kern P, Bambauer R, et al. Efficacy and safety of a new whole-blood low-density lipoprotein apheresis system (Liposorber D) in severe hypercholesterolemia. Artif Organs 2003;27(12):1116-22.

15. Hershcovici T, Schechner V, Orlin J, et al. Effect of different LDL-apheresis methods on parameters involved in atherosclerosis. J Clin Apher 2004;19(2):90-7.

16. McLeod BC, Szczepiorkowski ZM, Weinstein R, et al. Apheresis: Principles and practice. 3rd Edition. United States AABB, 2013; 205-10.

17. Luirink IK, Determeijer J, Hutten BA, et al. Efficacy and safety of lipoprotein apheresis in children with homozygous familial 
hypercholesterolemia: A systematic review. J Clin Lipidol 2019;13(1):31-9.

18. Moriarty PM. LDL apheresis therapy: Current therapeutic practice and potential future use. Future Lipidol 2006;1(3):299308.

19. Adorni MP, Zimetti F, Puntoni M, et al. Cellular cholesterol efflux and cholesterol loading capasity of serum: Effects of LDL-apheresis. Journal of Lipid Research 2012; 53:984-9
20. Kaplan A. Complications of apheresis. Semin Dial 2012; 25(2):152-8.

21. Julius $U$, Fischer $S$, Schatz $U$, et al. Why an apheresis center should offer more than one lipoprotein apheresis method. Therapeutic Apheresis and Dialysis 2013;17(2):179-84. 